\title{
Evaluation of Contemporary Art in terms of Conceptual Structure and Interpretability
}

\section{Research Article}

Hatice Nilufer SUZEN ${ }^{1}$

${ }^{1}$ Pamukkale University, Faculty of Education, Department of Art Education, Denizli, Turkey, ORCID: 0000-0002-2020-5551

To cite this article: Suzen, H. N. (2021). Evaluation of contemporary art in terms of conceptual structure and interpretability, International Online Journal of Educational Sciences, 13(2), 447-460.

\begin{abstract}
ARTICLE INFO
ABSTRACT

Article History:

The aim of this research is to examine the skills of 4 th grade students who are studying in Department of Painting within the Faculty of Fine Arts on evaluating and interpreting contemporary art concepts

Received: 18.06 .2020 and transferring theoretical knowledge into practice. The research data were collected through focus group interviews with 17 students studying at Uşak University, Faculty of Fine Arts Department of Painting.At the end of the study, the painting department students have certain qualities such as

Available online:

15.04.2021 being open to innovations, self-development and keeping themselves updated, respecting art and the artist, perceiving art and art object as a means of social change or unification and eagerly transferring this information into their own art products.In line with the findigs of the research, developing and diversifying creativity, establishing new ideas, having critical thinking capabilities, being aware of the necessity of comparison, curiosity and philosophy for creating an artwork, valuing the concept of originality rather than imitation, using technology and making field-specific readings within interdisciplinary dialogue to access a broad range of freedom through futuristic approaches and following the artists who are experts in their fields have been deemed important and necessary in line with the findings of this research.
\end{abstract}

(C) 2021 IOJES. All rights reserved

Keywords:

Art, contemporary art and technology, contemporary art interpretations

\section{Introduction}

Contemporary art has been transformed into a more complex narrative that is often associated with modernism within temporality. However, with the idea that the word "contemporary" is now the general name of an art concept rather than its temporal meaning, it can be said that the frequent use of contemporary

${ }^{1}$ Corresponding author's address: Pamukkale Üniversitesi

Telephone: +905052401836

e-mail: hsuzen@pau.edu.tr

DOI: https://doi.org/10.15345/iojes.2021.02.008 
and modern interchangeably results primarily from a translation problem. The views of Vasif Kortun, who placed the concept of "contemporary" into art in Turkey has been taken as the reference; "Kortun states that the concept of modern smells of statism, elitism and forced secularism, and that it does not meet the concepts such as contemporary and actual in English and therefore prefers the concept of contemporary". Thus, we can say that both the discomfort felt from the official policy and the choice of translation played a role in arising of this discussion" (Yllmaz, 2006). In this sense, contemporary art is a general concept that points to more than one trend, movement, genre, or element. Also, there is no integrity in themes. Some artists question the past while some of them question the moment they live in and some of them question the socio-cultural complexity while some of them question the nature of art.

The word "contemporary" is sometimes used as a term that avoids answering the time we are in and questions about when it started. It has become difficult for audiences to put forward clear and understandable opinions that the work that has been formed and presented is an art or not. However, the structure of contemporary art that supports harmony has both constructive and destructive messages and opens the way in intellectual terms. It mirrored politics and moral values and triggered different perceptions and thinking in the audience (Kapar, 2019).

What do we see when we look at a piece of art? Art makers and art viewers can see the same object differently, and these comments become more diverse against a broad range of times and cultures. Throughout the years, it has been thought that art has a meaning; it is important and attracts human beings. We place a visual material on some kind of independent existence, which allows us to see the world around us in different ways (Arnold, 2019). A man behaves according to the form, surface and mass of what is put before his senses. We enjoy arranging the form, surface and mass of things according to certain dimensions. The sense of beauty is combination of pleasant connections (Read, 2014). Even though we have specific reasons for defining something as art, the real truth is related to the social, cultural and historical values which are constantly evolving. Above all, the art is a work of its own time, and what is to be considered as an art is mostly a result of historical conditions (Whitham \& Pooke, 2018). According to Sözüer's citation from Şiray (2019); considering the unlimited freedoms defined by contemporary art in terms of practices, materials and technologies; the artwork shows itself as a production which puts forward the opinions of an artist with regard to a certain subject which is peculiar to the moment in which it is involved. This place the state of being art on a plane related to the "moment" itself. This information tells that a contemporary work can only be deemed as an art as soon as it is hanged on the wall of a gallery. While it is still early to name the function of this phenomenon in the history of art which is self-existing and self-reproducing without a movement, style or manifesto on its basis such as Postmodernism, Dadaism, Futurism; this art which tends to present the moment under the name "modern" actually expresses what is still being formed.

For Tolstoy, expression of feelings is not enough for creating a good piece of art. The reason behind it is not mere satisfaction, but also the expression should be understandable and sincere, and most importantly, should reveal the behaviours and thoughts of its age. The artist becomes more sensitive against his feelings and his needs through a well-performed piece of art (Aktr. Barrett, 2017).

While contemporary art imposes very different values on formal or abstract images, the developments behind it are indeed a revolution in terms of absolute autonomy (Girgin, 2018).

In the 21st century, when the need for creativity and cultural awareness increased, artistic awakening and original creation emerged as important tools for recognizing and interpreting the concepts of "contemporary" and "contemporary art". This research has been prepared in order to highlight the semantic relationship between contemporary art and art object, the way of thinking configured by the artist, the importance of current / contemporary art education which deals with concepts and objects in the quest to interpret the dimension of creativity and the necessity of increasing the quality of education. 
In order to determine whether the students studying in Painting Department of Faculty of Fine Arts, are aware of the concept of "Contemporary / Modern Art" and to make these students adopt the definition, conceptual knowledge and awareness of Contemporary Art, which is an interdisciplinary field, the research was conducted by means of revealing the current situation in order to enrich the artistic disciplines of these students. In the research, it has been concluded that, with the change of both education and practice levels, Contemporary Art courses will be more effective and positive if supported not only theoretically but also practically. For this purpose, in the research, answers were sought for the opinions of Painting Department students with regard to addressing theoretical and practical dimensions of artworks in contemporary art classes.

\section{Purpose of the Research}

In this research, it is aimed to determine the approaches and views of the 4th-grade students studying in Painting Department of Faculty of Fine Arts on "Contemporary Art". The students' views on Contemporary Art were examined under three main dimensions. These dimensions are:

1. The meaning and definition of Contemporary Art,

2. The field and development of Contemporary Art,

3. Contemporary Art and Technology relationship,

4. Evaluation.

Since this research has the features of a qualitative research, the data obtained herein are deemed to be deep and rich. This study provides an opportunity to examine the Contemporary Art courses given at undergraduate level and to evaluate the meaning, definition, field, development of Contemporary Art and its connection with technology and the relations of its inner dynamics between each other from various perspectives.

Based on the course content and literature review, six questions were asked under the scope of categories which are organized as follows: What do you think the contemporary art is? What kind of artwork comes to your mind when you think about contemporary art? Why do you think contemporary art approaches were needed? How did it come about? Why do you think the artists needed different interpretations? For example, if you are going to produce an artwork, what kind of subjects do you focus on, how would you describe these subjects / themes? How is the relationship between Contemporary Art and Technology? How do you use technology in art works? What do you say to me when it comes to manipulative art? What would you tell about the contribution of interpretations of contemporary art to us and to art?

The evaluation results obtained in the research are thought to be significant as it will encourage Painting Department students to create an awareness exceeding the boundaries of time and space using technology, to diversify their artworks and to produce ideas within the scope of technology rather than just producing artworks in only two or three dimensions.

\section{Method}

\section{Research Model}

In this research, the students were evaluated in terms of interpreting, criticizing and evaluating contemporary art concepts, artists, and artworks to generate examples for themselves under the scope of the Contemporary Art lessons given at the undergraduate level and therefore the model of the research is descriptive. A research that is specified as descriptive tries to define an existing situation, phenomenon, problem, service, or education systematically. Qualitative research is defined as "a research method in which qualitative data collection methods such as observation, interview, and document analysis are used, and a qualitative process is followed to reveal perceptions and events realistically and holistically within the natural 
environment. (Yildirim ve Şimsek, 2006) Since this study is based on an interview method, qualitative data has been studied. It is an essential feature of qualitative studies that qualitative data provide enriched and holistic content to identify complex facts, events, or situations (Miles Huberman,1994). Besides, in this research it is aimed to evaluate the views and knowledge of final year students of Fine Arts Faculties, namely the artist or art educator candidates who are the most important and dynamic internal stakeholders, on universally holistic contemporary concepts and digital possibilities rather than a stereotyped art concept, and to make them understand art and the formation of an artwork, grab the philosophy behind it and produce art objects in the quality of messages. Therefore this study can also be counted as an effort to evaluate critical thinking skills.

\section{Study Group}

The study group of the research consists of 17 students studying in the Painting Department of Fine Arts Faculty located in the Uşak province. Depending on the purpose of the study, maximum variation sampling, which is one of the purposeful sampling methods, was used in determining the study group. The purpose of the maximum diversity sampling method is to reflect the diversity of individuals related to the problem which is studied in the sample to the maximum extent. In maximum diversity sample is determined in a way that is related to the problem and consists of analogousi variable and different situations (Grix,2010).

In this direction, it is not aimed to provide this diversity in order to generalize, on the contrary, it is aimed to try to find out whether there are any common or shared phenomena among the various situations and to examine the different dimensions of the problem according to this diversity (Marcyzk vd.,2005).

The purpose of the sampling method is not to provide generalizations. However, on the contrary, the purpose is to find out whether there are any common or shared cases among the diverse situations and to be able to determine different dimensions of the problem according to this diversity (Yıldırım ve Şimşek, 2006).

Data of the research were obtained through focus group interviews. Semi-structured focus group interview forms were used in the interviews performed with Painting Department students. In the interview form, students were questioned about their demographic characteristics, contemporary art, philosophy of art, art psychology, interdisciplinary art practice courses they received in previous years, and general information about the background they acquired in these courses. The interviews were mostly performed based on mutual dialogue and sometimes using the brainstorming technique and discussion method to make dialogues more dynamic. Students participating in focus interviews were coded as S1-S2 within the scope of the study. Of these participants, 9 were females, and 8 were males. Participant students were in fourth grade and have completed the courses of art philosophy, art psychology, art criticism, western art, and interdisciplinary art practices in their undergraduate education programs.

\section{Data Collection Tools}

In-depth information was collected by using the interview method in the research which is among the qualitative data collection techniques. The interview is a technique of data collection through verbal communication and is performed to reveal what is going on through the mind. The interviews were conducted with a semi-structured interview form consisting of open-ended questions and which has been developed by the researcher. In preparing the interview form, the purpose, content, acquisition, methods, and techniques of Contemporary Art courses were reviewed and then literature was scanned. Based on the course content and literature review, six questions were asked under the scope of categories which are organized as follows: What do you think the contemporary art is? What kind of artwork comes to your mind when you think about contemporary art? Why do you think contemporary art approaches were needed? How did it come about? Why do you think the artists needed different interpretations? For example, if you are going to produce an artwork, what kind of subjects do you focus on, how would you describe these subjects / themes? How is the 
relationship between Contemporary Art and Technology? How do you use technology in art works? What do you say to me when it comes to manipulative art? What would you tell about the contribution of interpretations of contemporary art to us and to art?

First, a pilot interview was held with three students. The interview form was examined in terms of applicability and the mentioned six questions were rearranged by the researcher with regard to applicability and understandability. For example, the question "What is contemporary art?" was replaced with "What kind of artworks comes to your mind when you think about contemporary art?"

\section{Analysis of Data}

Content analysis method, which is frequently used in social sciences and qualitative research, was used in the research. Contect analysis is " systematic, repeatable technique in which some words of a text are summarized into smaller content categories with codings based on certain rules" (Büyüköztürk ve diğerleri 2013: 250).

Content analysis requires a more detailed analysis of the collected data and access to the concepts, categories and themes that explain this data.content analysis focuses on the collected data; Codes are extracted from events and facts that are frequently repeated in the data set or that the participant emphasizes. You can go from codes to categories and from categories to themes. Briefly, data (codes) that are determined to be similar and related to each other are brought together within the framework of certain concepts (categories) and themes and interpreted. In the content analysis, the content of the opinions of the participants is systematically separated (2019, Bengtsson, 2016; Crabtree ve Miller, 1999; Merriam ve Grenier, 2019, Aktr; Baltac1).

The data obtained through these interviews have been classified under 21 themes in total (for example; contemporary art, conceptual art, art and culture interaction, art psychology, etc.) and 72 categories were obtained (for example, originality, creativity, awareness, technology and art, philosophy of art, etc.) and it has been shown in the analysis results that these aforementioned themes could be expressed under 15 suprathemes. As it allows interpretation of research findings both in short and meaningful way and as it is more important for the purpose of the research, the findings were discussed based on 5 supra-themes (Yilmaz ve Eren, 2016). These supra-themes are: art, artist features, artist comments, art-society relationship, art and technology. The explanations and comments related to mentioned themes are given below.

\section{Findings}

To determine the views of 4th-grade students studying in Painting Department of Faculty of Fine Arts on "Contemporary Art" approaches and practices, the students' perceptions about the subject were determined in-depth within this research. The resulting 5 themes are listed in Figure 1 and the findings are presented accordingly. The codes belonging to each theme and citations devoted to their perceptions are discussed in detail. 


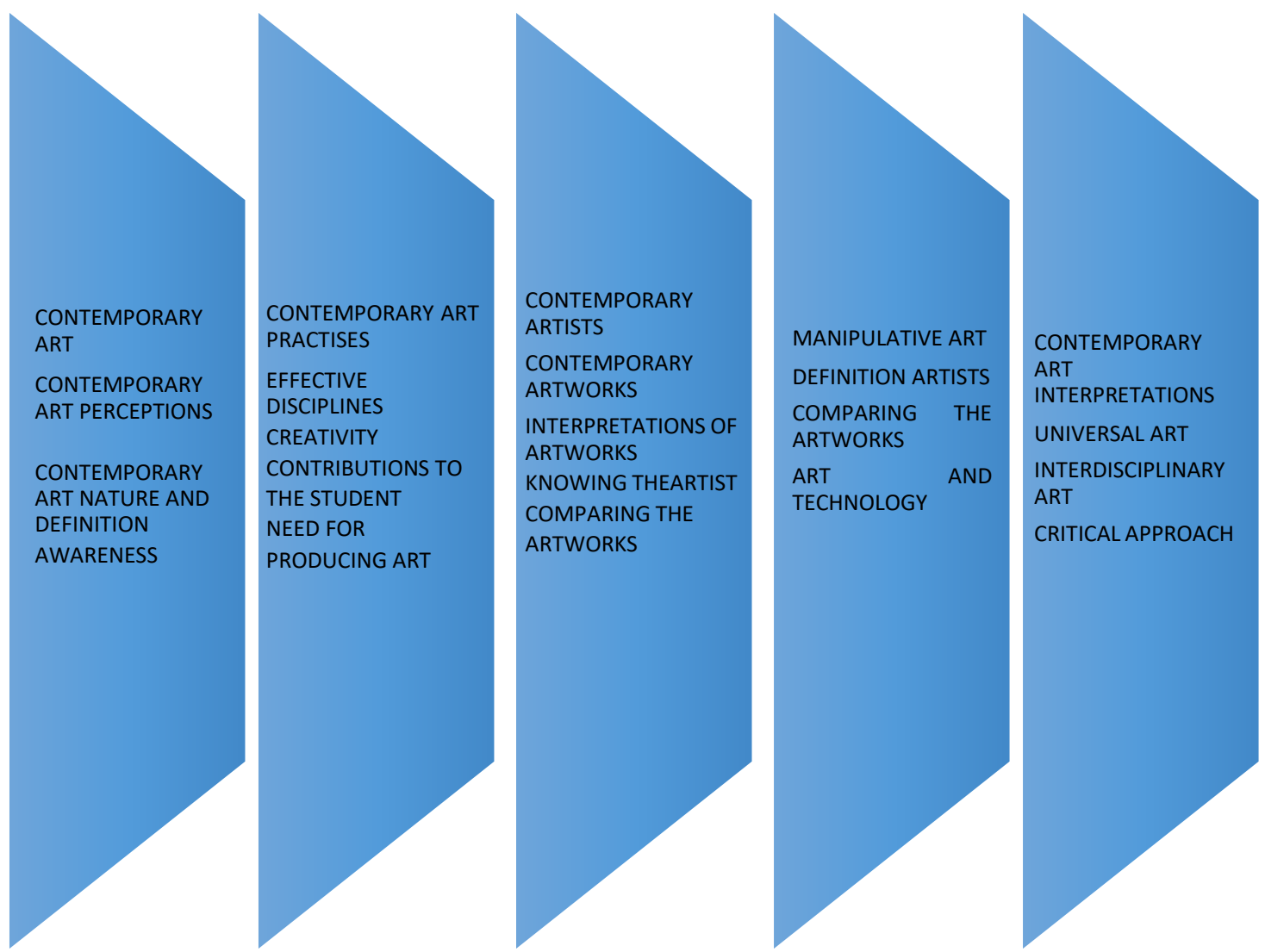

Figure 1. Interview Findings

1) What do you think the contemporary art is? What kind of artworks comes to your mind when you think about contemporary art?

Student S3 "Contemporary art or modern art is the art that has separated from the classical art concept and has been reshaped in line with the world view and the needs of the society, and whose means of expression have been transformed into all kinds of materials rather than a classical canvas. The important thing in contemporary art is to convey the expressed idea in the best way".

Renaissance artists who adopted and developed the view that art is a means of taste and teaching, have combined selective naturalism and mathematical ratio principles of Greeks which paved the way for beauty and Aristotle's rule of dramatic unities which paved the way for didacticism (Lynton,1991).

Student S7"Contemporary art is an ongoing process that dates back to 1950s. Different materials and expression methods have been used in contemporary art rather than just painting on a canvas. Apart from the canvas, they used methods of expression which they can express themselves better, such as video art, assembly, digital art, installation, performance art."

Nowadays, artists are almost programming forms rather than creating them. Instead of transforming an unprocessed material into a perfect shape, they reuse existing forms with remixes (Girgin, 2018).

Student S14, "Literally, contemporary art has emerged from modernist and postmodernist breaks that have moved away from academic art. They were named as art movement or movements. It includes new media art, poor art, conceptual art, feminist art, etc. In the changing world, art does not stay where it is. Art is also renewing itself. Years are passing and materials, technology, people and ideas are changing and more current ones are emerging". Interpreting the 
conceptual objects and practices of art in a more independent and original way and producing their own artworks with these new methods are becoming widespread.

Student S4 "It can be defined as following the society, culture, agenda and technology very closely, not remaining indifferent to this progress and change; revealing current or old events and situations experienced before and combining the old with today, in other words "the moment". In fact, we can say that the artists and their works performed at present and in recent dates are parts of contemporary art. It is an art adventure that took place recently. We can talk about a process that takes in many interdisciplinary studies. It is a process that brings with it many fields and materials such as installation performance, digital art, manipulative art, conceptual art, feminist art, hyperrealism for meeting the audience. Besides, we can tell that it is a process that cares more about the idea and questions the aesthetic judgment".

Such multiplicity, interdisciplinarity and repeated use of artworks is not only a surprising and repetitive understanding, but also it is something brought by a postmodern process and will demonstrate more distinctive differences in contemporary art.

\section{2) Why do you think contemporary art approaches were needed? How did it come about?}

Student S2 "Contemporary art emerged entirely due to the necessities of society and a worldview which is constantly updating and developing. Artists also must stay up to date".

The fact that art has ceased to be just a spectacle and took place in our world as a new reality provided a new awareness for the artist. XX. Century artist is the creator of "new reality". He/she shapes the technical world between man and the world and also plans the future and designs the "possible worlds" (Ípşiroğlu ve İpşiroğlu, 2010).

Student S4: "That's like we buy newspaper every day. You cannot interpret today with the newspaper of the last year. Contemporary artists have always used current ways to interpret today". The development process of art is to some extent a departure of pure and infinite art from the elements of subjectivity and time. Any era wants to reflect itself and expresses its own life in an artistic way (Kandinsky,2009).

Student S5, "The reason why we need contemporary art is to criticize the society, to make references, to surprise the audience and to make them comment. For example, Nam June Paik's putting televisions on top of each other is for explaining that each television is a member of society and thus he is making references to our relationship with television. Andy Warhol's reference to ready-to-eat society with Brillo boxes and soup cans may be another example for that.

Nam June Paik has chosen television, which is used as a very successful tool in manipulating human mind, as an art material and made a criticism against the system by changing the functions of the monitors.

Student S1"Actually, when we look at the history of art, we see that there was a classic progress until modernism and postmodernism. There were artist-oriented approaches telling that art was only for art and the audience was in the background while the artist was in the forefront. As a result of change in time and the world and due to increased questioning of artists and advancement of science and technology, the arts and artists were affected by these factors and they started to question more, benefited from the technology in their works and kept up with the change. The artists also questioned how they could convey more ideas with fewer objects and moved in this direction.

"Art is an escape from chaos. It is a move expressed in numbers. It is a mass bounded by measures. Art is a material instability that seeks for the harmony of life" (Read,2014).

Student S17, "It is somehow getting away from academic art, abstraction and conceptualization together with the enlightenment since the end of medieval period. Thoughts replaced the practise of conveying what is seen, mostly based on rules, as it used to be. Through the process of development, man tends from classic to different. To give an example, especially before the 19th century, a wide-ranging enlightenment in the world had just begun, and these were the times when painting and art were made to aid other sciences rather than a means of expression, or only for money and profit. 
And it was reflecting the characteristics of that period, religious teachings, daily life or noble portraits. If we look at the contemporary art, we can tell that the biggest reasons for this necessity are people's desire for science and technology, because religious teachings have been left behind and people needed to criticize. Transcending borders are the quests to convey a thought in the most different ways.

The artist is based on the society, takes his tone, speed, and violence from the society of which he is a member. Nevertheless, there are other things that the unique feature of the artwork depends on. Art depends on the artist's desire to give a definite form, which is a sign of his/her personality, and without this temptation, a significant artwork cannot be created.

The artist relies on his/her mind or instincts when establishing the composition, or perhaps he can use a little bit of each of these ways (Read, 2014).

\section{3) Why do you think the artists needed different interpretations? For example, if you are going to produce an artwork, what kind of subjects do you focus on, how would you describe these subjects / themes?}

Student S14 "Contemporary art is a stream of art that is constantly being renewed and updated. With the development of technology, contemporary art has been involved in many fields and covered many movements such as video art, digital art, performing arts. As the currentness increases, the way of expressing the events also changes. Thus the artist also changes his/her way of expressing his/her point of view and finds him/herself involved in interdisciplinary art".

Art practices are formed with the transformation of design aesthetics into different strategies. The works are designed by means of understanding the object and the experiences, performances, concepts and images of contemporary art (Şahiner, 2015).

Student S9, "Art is universal and the culture of each artist, what they see, their experiences, their way of thinking, philosophies, the reactions of society, the possibilities and conditions of materials they can use, nationalities, traditions, etc. vary from one to another. Therefore, the works of the artists also emerge as a result of different interpretations. The artists try to bring these different comments to their audience. We can say that there is an interdisciplinary situation. If we come to the question of what I would do; As a Turk, I would adapt our own culture to the present and make universal works by combining past and present with art.".

In our age, art is generally understood as a form of social communication. It is a communication-based effort of being accepted. All people want to communicate (Groys, 2014).

Student S2, "Every artist needs different interpretations. Not everyone is the same. The environment in which they live and the people with whom they interact are the factors that make the individuals who they are. Artists are striving to express themselves".

The diversity of the ways followed in the artistic world in terms of number and variety depends on the environment in which it is involved and the sources it benefits from; just like in the nature (Klee, 2006).

Student S11, "I think the reason why artists need comments, reactions and criticism that he/she will receive from the audience is the desire to work more which is awakened inside the artist by the mentioned audience. In order to arouse curiosity, artists gathered different materials and produced artworks using them. I would also create such works for whatever kind of message I would like to convey in a way that would intrigue people. I would like to see how the audience will react, how they will comment, how they will criticize.

The symbol is an embodiment that occurs only through the formation and limitation of uncertain and personal excitements. Many of the artworks benefit from such a symbolic form, perhaps without being aware of their appearance (Read,2014). 
In a sense, the work of art is the salvation of personality. Normally, our feelings are under pressure and restrained. When we dwell on a work of art, a sudden discharge happens. This is not just a discharge but also a rise, tension and glory. This is the difference between art and emotion: art is a frugal emotion, a well-forming excitement (Read,2014).

According to Girgin's citation from A.Malraux; "Every artwork is inspired by another artwork".

\section{4) How is the relationship between Contemporary Art and Technology? How do you use technology in art works?}

Student S15 "Contemporary art can benefit from technology in every sense. With the development of technology, new art searches and new art movements have emerged. Such as digital art or video art. Kinetic art or giant sculptures also use technology during the art forming process. Here, importance has been given to technology's facilitating the art process and intensifying the thoughts".

Art and artists, who have been in closer relationship with technology, have introduced new experiences by reflecting differences in emotional perceptions with the use of electronic media (Tuğal, 2018).

Student S8 "Nam June Paik made video art, video installation and video sculptures using materials such as computer etc. in his artworks performed as a criticism against technology.

Joseph Boys, Maria Abramonovic, Yves Klein etc. used technology as an effective method of expression. Technology has been used in new media, video art, hyperrealist (realistic) works and has made the narration strong and effective".

Advances in technology have accelerated the unification of disciplines, conducting reliable experiments, and convergence in the fields of cinema, video, painting, sculpture, music and design.

Student S7, "Contemporary art is mostly associated with the technology. Especially new media art, including digital art, coding art, etc. is the state of art that is blended with technology. I am now actively using digital art such as gaming design or graphics. I am feeding myself with technology and contemporary art.

The art turns into a desire for visualizing the invisible. İsmail Tunalı talks about the expression concept of art in his book "Modern Painting in the Light of Philosophy" and states that art is understood as the superiority of the subject (I) to the object and as the superiority of the inner world to the outside world. (Tunalı, 2008).

Student S12, "We can say that the world is experiencing the technology at a high level and it is not possible ignore the current technology while producing an art object in this regard. If it does not reflect its agenda, history, society, economy and technology and is not progressed in line with this direction, it would not be called contemporary art. If I were to produce an art object, I would benefit from the possibilities of technology."

Technology continued to develop rapidly, but the two world wars and similar events had enormous impact on world art. Art always reflects the spirit of its time. A large number of artistic movements have been born since the beginning of the 20th century. These were either named by others or announced by young artists trying to break old academic traditions and create a bold new art world (Hodge, 2016).

Student S10, "Technology is present in every point from culture to art, and it shows up in many social platforms with its requirements, advantages or disadvantages. While it serves a regulator facilitating the life, it has also shown itself within the framework of contemporary art by reaching many people. Mostly the new media art. Of course, I also use the technology of digital art in my works. Video art, for example".

When a feature like the use of modern technology is added, the boundaries become wider. The mechanical repetition of an artwork with replicas and printing techniques as well as photography and cinema is more effective today with information technologies such as the Internet. The artwork can always be 
reproduced and these artworks which are reproduced using technical possibilities do not lose their "spirit" or aura or its special expression aesthetics and its holiness indeed. (Girgin, 2018).

\section{5) What do you say to me when it comes to manipulative art?}

Student S9 "It is to place a thought in people's mind with subliminal games without making them aware. German artist Anselm Kiefer (Carbonated Art) is inspired by the soil. In his paintings, he repeats awareness and the history that humanity should not forget, by using materials such as blood, earth, sea, lead and bark. Anselm Kiefer tells that: "my art is a document of the time". He continued his studies with mythological legends by addressing topics such as war, depression, Nazis and Hitler".

Kiefer was believing that the artists were endowed with mystical powers which allowed them to describe natural powers that others would not have noticed. He produced many paintings, sculptures, engravings, and photographs where he depicted violence (Hodge, 2016).

Student S6 "Manipulative art is the illusion that artists make in their work. It is motivation. The act of misleading for increasing the credibility of anything is called manipulation. An example of this is Marcel Duchamp's "Fountain". After Duchamp, who changed the history of creativity by presenting any action or any object as an artwork and shook the belief that art should be based on skill and talent in the traditional sense, the phenomenon of artistic skill has lost its importance."

With this work, Duchamp explained that modern artist is not a monarch and presented an art example by opposing to the questions like "Should art first appeal to the eyes, not to the mind? Is converting some materials considered art or can the value of a previously made object be determined only over its price? (Hodge, 2016).

Student S16, "Manipulative art shows something different than it is in reality. We can call it as interventions made over the truth. Andy Warhol's Mona Lisa for example. Mona Lisa is the famous painting of Leonardo as we all know. Warhol made a criticism of this painting and put a moustache on Mona Lisa. We can call it as playing with the perception. For example, when we show this picture to a child, if he/she has never seen Mona Lisa before, he/she always accepts and remembers her with that moustache. But as we know its original, we understand that there are manipulations on it. We can give examples of artists like Burhan Doğançay, Bedri Baykam, Ekrem Kahraman".

Andy Warhol confronted the audience having established beliefs about art, consumer culture, uniformity, originality, individuality and recognition in both high and low cultures.

Student S4, "Manipulation is a mind game for taking people under control. While it is done on purpose most of the time, it can also be performed without knowing it. The person moves people according to his/her own wishes. Important artists such as Ekrem Kahraman, Hasip Pektaş (works like "doğadan anılar" or "Kâ̆ğthane"), Hüseyin Elmas are representatives of manipulative art. Artists are people coming from different cultures and environments and they perform their art in order to express themselves. If a person chooses art as a form of expression and does not like someone else's expression, he has to attract people into his own thoughts. Even if this is an intervention in somebody else's artwork. The artist has sought many ways to express himself. Many movements have emerged on this road with obstacles. One of them is manipulative art."

Student S10: Manipulating is primarily an attempt to show an existing reality differently than it actually is. It is changing artworks which are previously made in order to be introduced again and making the audience accept that this is the correct one perceptually.

Nowadays, there may not be a connection between reproducing previous artworks such as imitation and citation or developing own artistic experiences. Nevertheless, it is noteworthy that the artist prefers to "use an artwork" rather than quoting directly from the nature. Therefore, the artist's preference to use quoting, citation and imitation as a tool in art production encodes a conscious attitude (Girgin, 2018). 


\section{6) What would you tell about the contribution of interpretations of contemporary art to us and to art?}

Student S5, "This art deals with the forms of expression more broadly and handle with the ideas in the best way possible. It made the art to gain a more different dimension. Contemporary art has achieved this by reaching more and more people with new forms of expression on the contrary to the traditional art."

The artist who gives up all side meanings based on descriptions in contemporary artworks, focuses on mechanical and pictorial features, including colour, light, line, shape, space, proportion and scale and create artworks that discover the anger and excitement of the state of being human. It aims to reveal the secret of creation and the approach between the process and the resulting object.

Student S13, "This separated the art from its plastic and rigid effects and broke down the general judgments. Art has become "art for everyone", "art everywhere", "art with everything". The perception of art as a hobby or a difficult pursuit has been broken down and the importance of expressing the thought has been revealed.

As the artists reached the senses of seeing, touching and tasting secretly and intelligently in their works, they directed the audience to carefully evaluate and question the past and the future. Change and movement is an allegory about the world. The main thing is to express the fragility of life and art. In contemporary art, the artist turns the audience into participants rather than someone just passing by. Every art audience has the opportunity to participate in the movement, cause change and ultimately affect the balance of understanding and interpreting the art and the art object.

The $21^{\text {st }}$ century is a time when the traditional sense of aesthetics and the usual ways of seeing in art were torn down. In addition, the art met with modernism thanks to the art activities / art practices performed with interactive and massive participation. All these developments in art in the last 50-60 years can be explained with the current understanding of art emerging with the disappearance of interdisciplinary borders in addition to various interconnected factors.

\section{Discussion and Result}

As stated by the participant students whose opinions were taken in the research, the concept of contemporary art is sometimes used simultaneously with modern art. In this sense, it is necessary to read the new media art, the artists and their works within the frame of contemporary art through the eyes of more qualified viewers. These readings can only be possible with correct and satisfying knowledge. The educators of art have great duties in this respect.

According to Barrett (2017) citing from Cynthia Freeland; cognitive art views are expressed as follows:

1) Artworks trigger cognitive activities, which teach us something about the world.

2) The cognitive activity they trigger is a part of their functionality.

3) As a result of this triggering we learn from that artwork. We get new information, our beliefs are refreshed and our understanding deepens.

4) What we learn in this respect is one of the reasons why we enjoy art and evaluate artworks. He acknowledges the need for complex interpretation in the content of an artwork. Contemporary art does not bring new solutions or suggestions, but on the contrary, it raises new questions. The main problem or mystery for the contemporary art comes with the concepts "modern" and "contemporary" (Eroğlu, 2013). Rather than being trapped between traditional and future and falling into copies and repetitions, it is essential to provide opportunities for contemporary art approaches to be included in the curriculums and to provide opportunities for such art events in publicly available platforms.

It is not possible to understand current art practices by sticking to a single sensation, approaching with a single discipline or trying to analyse it with conventional methods because such methods will always lead 
the person to wrong conclusions. Because multi-layered works that are created as a result of the cooperation or support of multiple disciplines are counted within the concept of contemporary art.

Contemporary art practices have an integrated structure which is created by bringing together at least two disciplines in production, presentation or reading and cannot be defined by a single art discipline and possess a rich and complex feature with more than one dynamic inside it. As a result of interdisciplinary fusion in artistic activities, this kind of approach as used in the art must be primarily evaluated as a contemporary art style and art culture.

It is possible to use the concept of contemporary art for almost all art styles or trends that emerged after 1950-60s. The artists performing in Video Art, Internet Art and Digital Art, Installation, Fluxus, Performance, Process Art, Environmental Art and any product, work, practice, piece of art or activity produced by each and every artist today are the types having heterogeneous structures. Waste materials, found objects, scribbles and written expressions, as well as technological materials such as photographs, films, videos and the Internet provide diversity in the perception of art.

Based on the fact that the process is at the forefront rather than the result in contemporary art practices and no matter whether they are close or far apart, analysing of art practices created with the cooperation and background of multiple disciplines with a multicultural (with multiple discipline cultures) approach is important and actually is a necessity for correct understanding of these practices. Based on the subjective qualities of the contemporary piece of art, it has been concluded that it should be analysed accordingly.

In this respect, in order to ensure the continuity of meaning in contemporary art, the receptor / audience who is aiming to be a sample reader, must also take into account the specific characteristics of the artwork during semantic analysis. The audience of contemporary art must be able to analyse the conceptual depth of the piece of art he/she is impressed with and must understand the reason why he/she is impressed.

The art of today in terms of the techniques used, accommodates innovative approaches involving different media and in fact sheds light on the types of production of art in the future and does not merely display a forward and unidirectional temporal orientation. On the contrary, while presenting new technologies that have not been tried in the context of art, it also covers traditional approaches and mastery techniques on the same plane and provides a broad interdisciplinary freedom of production.

One of the most common discourses in the field of art education is about the contribution of art education to the development of creativity. Creativity can be developed through innovative and modern art education methods that balance the abilities of students such as developing new ideas, critical thinking, and transferring theoretical knowledge into practice. Art education refers to a deep and long process consisting of many steps such as creative thinking and re-evaluation. In this sense, a person without any artistic view or philosophy cannot be successful in art. If there is objectivity and subjectivity in the field of art and art practices, support should be given to students' contemporary art interpretations and knowledge. The power and limitless nature of the art helps us in establishing common contemporary art ideas and views as well as in specifying and interpreting the art object. In this regard, the students must be encouraged to attend the events like Biennials and Triennials which are frequently held in the whole world and in our country with the identity of an artist or just an audience. Students' views on art and art production should be expanded and they should be supported to embark on an art life with a wide perspective with national or international exhibitions, panels, workshops, speeches and video screenings which will help them work more actively. This kind of approach will positively influence the students of Painting Department in Faculties of Fine Arts, and will support them to become a real artist. 


\section{REFERENCES}

Arnold, D. (2019). (çev. Atalay, G.) Sanat Hakkında Kısa Bir Kitap. 1.Baskı. Hayalperest Basımcılık. İstanbul.

Baltacı, A. (2019). Nitel araştırma süreci: Nitel bir araştırma nasıl yapılır? Ahi Evran Üniversitesi Sosyal Bilimler Enstitüsü Dergisi, 5(2), 368-388.

Barrett, T. (çev. Ermert, E.). (2017). Neden Bu Sanat? Çağdaş Sanatta Estetik Ve Eleştiri. 1. Baskı. Hayalperest Yayıncllık. İstanbul.

Büyüköztürk, Ş., Kılıç Çakmak, E., Akgün, Ö. A., Karadeniz, Ş. ve Demirel, F. (2013). Bilimsel araştırma yöntemleri. Ankara: Pegem Akademi Yayıncılık.

Eroğlu, Ö. (2013). Sanat Tarihi Morfolojisine Giriş. Tekhne Yayınları. 1. Baskı. İstanbul.

Girgin, F. (2018). Çağdaş Sanat ve Yeniden Üretim Alıntı, Öykünme, Kolaj, Taklit. 1.Baskı. Hayalperest Yayıncılık. İstanbul.

Grix, J. (2010). The Foundations Of Research. London: Palgrave Macmillan.

Groys, B. (çev. Erdoğan, F.C.) (2014). Sanatın Gücü. Hayalperest Yayıncılık. 2. Baskı. İstanbul

Hodge, S. (2016). (çev. Çulcu,F.C.\& Metin,G). Beş Yaşındaki Çocuk Bunu Neden Yapamaz, Açıklamalı Modern Sanat. Hayalperest Yayıncilık. 2. Baskı. İstanbul.

İpşiroğlu, N ve İpşiroğlu, M. (2010). Oluşum Süreci İçinde Sanatın Tarihi. Hayalperest Yayıncılık. 3.baskı. İstanbul.

Kandinsky, V (2009). Sanatta Zihinsellik Üstüne. Hayalperest Yayıncllık. 1.baskı. İstanbul.

Kapar, S. (2019). Günümüz Görsel Sanatında Çağdaşlık Analizleri Ve Estetik Teoriler. Journal of Awareness, 4 (1) , 97-110. DOI: 10.26809 /joa.4.008

Klee, P. (2006). (çev.Dündar,M.). Çağdaş Sanat Kuramı. Dost Kitabevi Yayınları. 1. Baskı. Ankara.

Lynton, N. (1991). Modern Sanatın Öyküsü. Remzi Kitabevi. 2. Baskı. İstanbul.

Marczyk, G., Dematteo, D., \& Festınger, D. (2005). Essentials Of Research Design and Methodology. New York: John Wiley \& Sons Inc.

Miles, M, B., \& Huberman, A. M. (1994). Qualitative data analysis: An expanded Sourcebook. (2nd ed). Thousand Oaks, CA: Sage.

Read, H. (2014). Sanatın Anlamı. Hayalperest yayınevi, İstanbul.

Sözüer, Z.D. (2019). Güncel Sanatta Zanaatın Temsili ve Tekstil Yapıtları Üzerinden İncelenmesi. Yıldız Journal of Art and Design.6(1),1-13. Retrieved from https://dergipark.org.tr/tr/pub/yjad/ issue $/ 46289 / 512053$

Şahiner, R. (2015). Çağdaş Sanatta Temsiliyet Krizi Çağdaş Kuramlar ve Güncel Tartışmalar. Ütopya Sanat Dizisi. Baski. Ankara.

Tuğal, S.A. (2018). Oluşum Süreci İçinde Dijital Sanat. Hayalperest Yayıncılık. 1.baskı. İstanbul.

Tunalı, İ. (2008). Felsefenin Işı̆̆ında Modern Resim. Remzi Kitabevi.7. Basım. İstanbul.

Yıldırım, A., \& Şimşek, H. (2006). Sosyal Bilimlerde Nitel Araştırma Yöntemleri. (6. Baskı). Ankara: Seçkin Yayıncilik.

Yılmaz, M. (2006). Modernizmden Postmodernizme Sanat. 1.Baskı, Ütopya Yayınevi, Ankara. 
Yılmaz, S. ve Eren, A. (2016). Eğitim Sendikalarının Görsel Sanatlar Öğretmenlerinin Niteliklerine İlişkin Beklentileri. Ordu Üniversitesi Sosyal Bilimler Araştırmaları Dergisi, 6(3),877-894, Aralık 2016

Whıtham, G. \& Pooke, G. (çev.Göbekçin, T.) (2018). Sanatı Anlamak. Hayalperest Yayıncılık. 1.baskı. İstanbul. 